\title{
Cloning, Characterization, and Targeted Disruption of cpcat1, Coding for an in Planta Secreted Catalase of Claviceps purpurea
}

\author{
Victoriano Garre, Ulrike Müller, and Paul Tudzynski \\ Institut für Botanik, Westfälische Wilhelms-Universität, Schlossgarten 3, D-48149 Münster, Germany \\ Accepted 27 April 1998.
}

\begin{abstract}
Claviceps purpurea has been shown to secrete catalases in axenic and parasitic culture. In order to determine the importance of these enzymes in the host-parasite interaction, especially their role in overcoming oxidative stress imposed on the pathogen by the plant's defense system, the catR gene from $A$. niger was used to isolate a putative catalase gene from a genomic library of $C$. purpurea. cpcat 1 consists of an open reading frame of $2,148 \mathrm{bp}$ that is interrupted by five introns. Its derived gene product shows significant homology to fungal catalases and contains a putative signal peptide of 19 amino acids and three putative $\mathrm{N}$-glycosylation sites, which indicates that CPCAT1 is a secreted catalase. Disruption of the gene by a gene replacement approach resulted in the loss of two catalase isoforms, CATC and CATD, strongly suggesting that they are both encoded by cpcat1. CATD is the major secreted catalase of $C$. purpurea and is furthermore the only catalase present in the honeydew of infected rye ears. Deletion mutants of cpcat1 were inoculated on rye plants and showed no significant reduction in virulence. Ovarian tissue and honeydew of plants inoculated with the mutants lacked CATD, confirming that this catalase is not essential for colonization of the host tissue by $C$. purpurea.
\end{abstract}

Additional keywords: active oxygen species.

An important factor in the capacity of a pathogen to infect a plant resides in the ability to either tolerate or eliminate constitutive (Osbourn 1996) or induced (for review, see Hammond-Kosack and Jones 1996) toxic molecules produced by the plant cell. A further critical factor is the evasion of the pathogen detection system through the removal of molecules that could be detected by these systems, such as avirulence factors (Joosten et al. 1994). One of the first responses of a plant cell upon detection of a pathogen is the generation of reactive oxygen species, termed the oxidative burst (Doke 1983; Mehdy 1994; Low and Merida 1996). $\mathrm{H}_{2} \mathrm{O}_{2}$ produced during the oxidative burst is involved in several responses that

Corresponding author: P. Tudzynski; E-mail: tudzyns@uni-muenster.de

Present address of V. Garre: Departamento de Genetica y Microbiologia, Facultad de Biologia, Universidad de Murcia, Apdo. 4021, 30071 Murcia, Spain.

Nucleotide and/or amino acid sequence data are to be found at the EMBL data base as accession number AJ001386. might contribute to the restriction of pathogen growth, such as cross-linking of cell wall structural proteins or phenolics (Bradley et al. 1992; Brisson et al. 1994; Otte and Barz 1996), triggering of rapid necrosis at infection sites, a phenomenon known as the hypersensitive response (HR) (for review, see Hammond-Kosack and Jones 1996), and could furthermore act directly as an antimicrobial agent (Peng and Kuc 1992). Despite these studies, mainly obtained from examination of plant cell cultures, there is only one case in the literature that shows convincing evidence that $\mathrm{H}_{2} \mathrm{O}_{2}$ is actually involved in conferring disease resistance on plants. In this study, the constitutive expression of an $\mathrm{H}_{2} \mathrm{O}_{2}$-generating glucose oxidase from Aspergillus niger in the apoplast of transgenic potato plants resulted in strong resistance to the bacterial soft rot pathogen Erwinia carotovora and in enhanced resistance to Phytophthora infestans (Wu et al. 1995). The resistance of the transgenic plants to soft rot was abolished when catalase was added simultaneously with the bacterium, consistent with the higher resistance being the consequence of $\mathrm{H}_{2} \mathrm{O}_{2}$ accumulation. However, the mechanism underlying this general resistance to these diverse pathogens is still unknown. If $\mathrm{H}_{2} \mathrm{O}_{2}$ plays a crucial role in plant defense, then the evolution of counteracting systems should provide pathogens with a major selective advantage in the colonization of plant tissue. The major importance of catalase is thought to be in its scavenging of toxic $\mathrm{H}_{2} \mathrm{O}_{2}$ by its conversion to oxygen gas and water (Natvig et al. 1996). Work with the phytopathogenic bacterium Pseudomonas syringae and the saprophytic bacterium Pseudomonas putida described the presence of several periplasmic catalases and a membrane-associated catalase, respectively (Klotz and Hutcheson 1992; Katsuwon and Anderson 1990). Recently, the secretion of catalase by Claviceps purpurea during the first stages of colonization of rye ovaries has been detected by means of biochemical and cytological techniques (Garre et al. 1998). Four catalases, differing in electrophoretic mobility, were identified in axenic cultures of C. purpurea. Catalase CATA, with an isoelectric point (IP) of about 5, could only be isolated from mycelia and is therefore probably an intracellular catalase. CATC and CATD (both with an IP of about 7), could both be isolated from mycelia and culture fluids, which indicates that these are extracellular catalases, whereas CATB (IP approximately 5.2) probably is cell wall associated (Garre et al. 1998). Of these, CATC was the major catalase in axenic culture fluids. Analysis of young infected ovaries and honeydew exuded from infected ovaries 
of rye revealed that CATD is the major secreted catalase in the first stages of infection, and could therefore be capable of nullifying the responses mediated by $\mathrm{H}_{2} \mathrm{O}_{2}$. The cloning of the gene encoding CATD would provide an opportunity to generate CATD-deficient mutants and to study the role of this protein during the colonization of rye ovaries by $C$. purpurea.

This paper describes the cloning and characterization of a fungal catalase gene, cpcat 1 from $C$. purpurea, that encodes a catalase secreted during plant infection. Analysis of mutants in this gene, generated by gene replacement, confirm that it codes for CATD, the major catalase secreted by $C$. purpurea during rye colonization, thus allowing us to evaluate its role in pathogenicity on rye.

\section{RESULTS}

\section{Cloning and characterization of cpcat1.}

The CatR gene from Aspergillus niger was selected as a heterologous probe for use in the cloning of the $C$. purpurea gene encoding CATD because it codes for a catalase that has typical attributes of a secreted protein (Fowler et al. 1993). An internal $1.75-\mathrm{kb}$ Sall-HindIII fragment containing the most conserved part of the A. niger CatR coding region was used in Southern blot hybridization experiments at different temperatures. At $60^{\circ} \mathrm{C}$, this probe strongly hybridized with few fragments generated by restriction of $C$. purpurea genomic DNA with several restriction enzymes (data not shown). The above conditions were used to screen approximately 50,000 plaques from a genomic EMBL3 library of $C$. purpurea strain T5 (Smit and Tudzynski 1992). Twenty of the strongest hybridizing plaques were selected for a second round of hybridization, which gave nine clear positive clones. The DNA extracted from these recombinant phages was restricted with SalI and hybridized with the A. niger CatR probe. Several fragments showed strong hybridization signals, with a $0.7-\mathrm{kb}$ fragment present in all of the nine clones. DNA sequence analysis revealed that this fragment encoded for an amino acid sequence with high similarity to the conserved catalytic do-

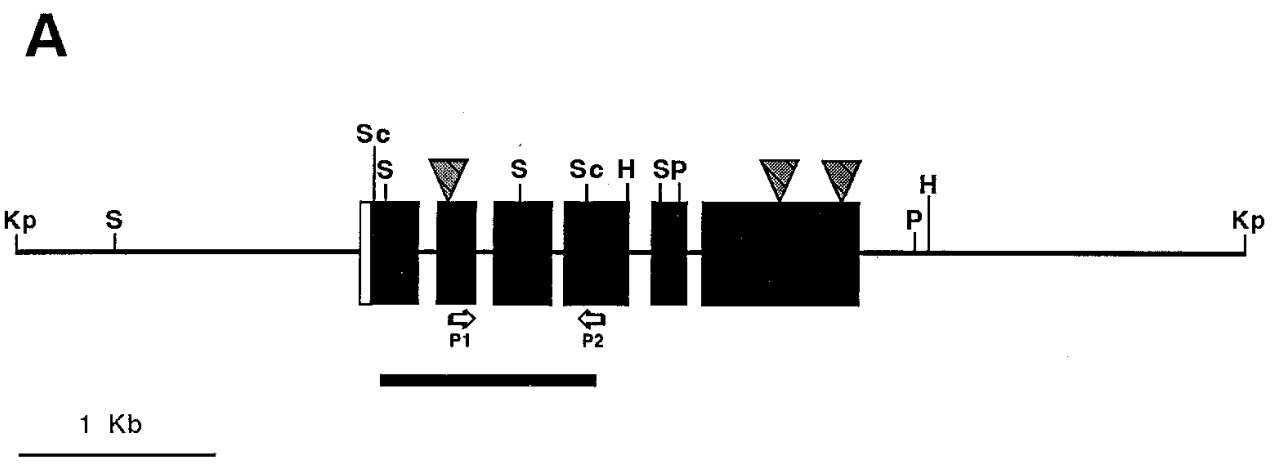

B
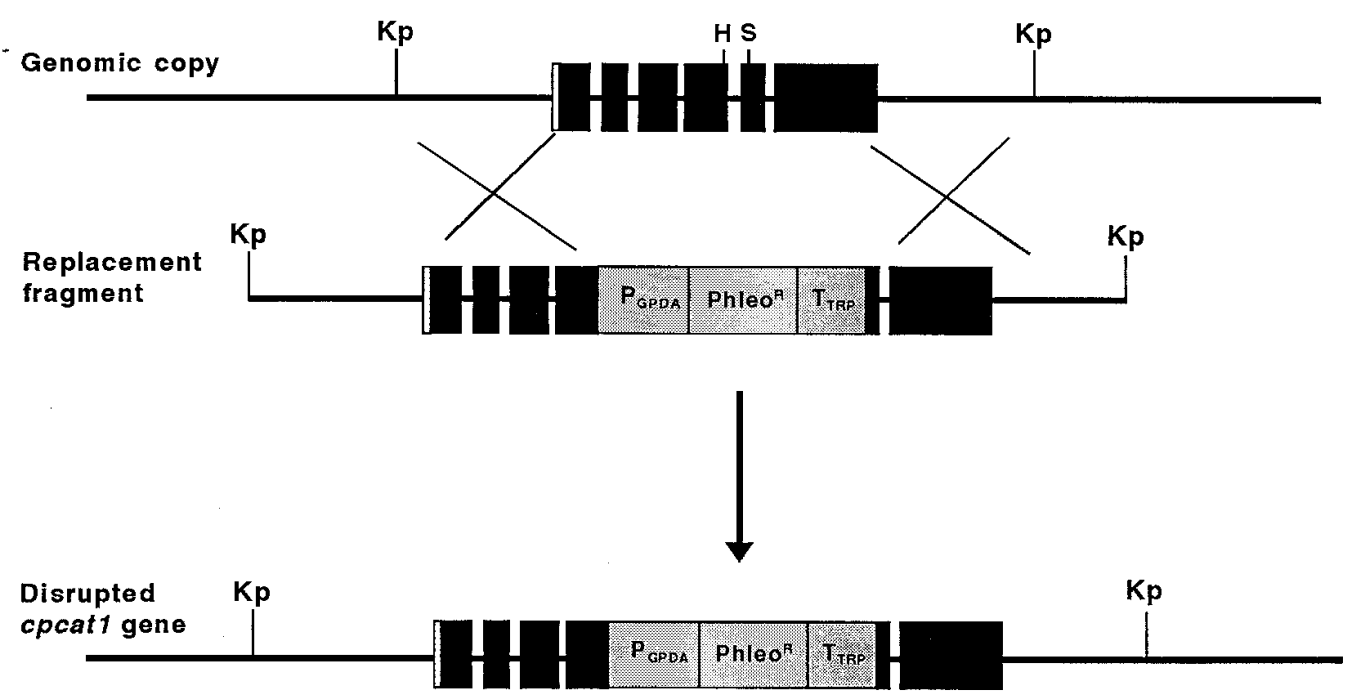

Fig. 1. A, Restriction map of the 6.5-kb KpnI fragment of Claviceps purpurea genomic DNA cloned in plasmid pcpcat1. Exons are indicated by black boxes; noncoding regions by a line; a putative signal peptide signal by a white box; and putative N-glycosylation sites by triangles. Target sequences for primer P1 and P2 are indicated by arrows. A solid bar indicates the 1.1-kb SacI fragment used as probe in Southern blot hybridizations in Figures 3 and 6. Restriction sites: Kp, KpnI; S, SalI; Sc, SacI; H, HindIII; P, PstI; B, Construction of the replacement vector pcp $\Delta$ cat 1. The internal 0.3-kb SalI-HindIII fragment was removed and substituted by the phleomycin resistance cassette from pAN8-1 (Mattern et al. 1988). The final genomic structure at the cpcat1 locus upon homologous recombination of the replacement fragment is shown. 
1 GGTACCTAGGTATGTACACCGTACACGTCGCCCGCTGATGCTGTCACTTGTCAAAGGCTTCTTCTTGCCCAGTTTCGCCCCGCCTGATTGACAGCCAGCA 101 GTAGACATGGATGGATGTTATGGCCTACGATCAGCGTCGCTTITTGGTAGTTGGATCGCAGCGAGAATGTGGGATGATGTACCTATGTAGGTAGTGTCAC 201 TGTGCACGGTACGTTTGCATCGACACACACTCAGTTCCCACATACATACTGCGAAGGGCTGATGCGCCGAAGACGAGGATTCTTTTCAGGGCCCATGTCT 301 ATACAGGTATCTTTGTACATATGTATCGGAACCTCGAAACTCTTGCGGCCTCACAGAATACTCCGTACGTAGACGAACTGCCACTGACAAATTGCCTTTG GATA GATA

401 AGGCATTAATCATGCTATCCATGACTTGCAAGTTGCCCTGTCCTGTGTCTCTTCATCCGCCCAATGCACATCGGGTCGACGTTCCGCCGCTGCTTGCTCC 501 ATGATCCGCTAATCTCCCCCGGAGGATCTGGATTTCTGGGGTCTGGAGGAGATGATGCCCCGCCAACTCAGTCTCGTCCGAGAACGATACAGCCCTTGGG CREA CREA CREA CREA GATA 601 CCTTGAGCCTACAAGAAACATCATCACAACGACTGTGATAGGTCAAATCCGCACCTGAAGAAACGTGCACCTAATTCTGGCTACACAGTCTCAAACCATC GATA

701 CCTGTCAAGACTCAAGAGTCGGACTCAAGACACTGCCCGGGAAACGAAAAAGCCCACGGCTCCGGTCGGTTCTTGCATCCGGCTCTGGGTTGGCTTGGCC 801 GTTGGGATTGAAGCCGCTTCAACATCAACCGCGTCACACAACATGGCCAATTTGGGGGCTACAGAGCGCGCGGGGAGGTGACTAGTAACTACCTACCTTA CAAT CREA

901 GGTAGTTCATCTGAGCATCACTCGACCAAGGTGTGATAGAATGACTGAGATAATATACCAATAGTTCTCATCCTAAACCTTATCTAAATTCCACCATAGA GATA GATA GAT

1001 TTCTGAGTCCTGACCATTCTCACACAGCTCTTTCTTGACTACATATGAGACTCTTTCTACGTCATGTGTATAGGATTTAGTTCTTCTTGCACCACCCGGA

1101 TCTCCGGTTGGGACCCAAGGGCCAAGATTGTAATGACTGATCGACCGACGACCGTCTTGTAGTCTACATCTCCCATGGTTGCACTGTACTCACCCTCGCC CREA

1201 CAACCTT'TCTAGTTTGGTGCAGGAAAGCCAACGGTATGAGCTACATACTCCGTATACTTCTAAAGTTATGTCCGGCCAGGGTCTTGGCCGGCAGATATAC

1301 TCCGTTCTIGCGCATGCAAACTCGAGACGCATGTTCCTGATGTGCTCCATCCGGTTAGCAAGCGTCCTGCCACCTCCTGCCTTCCCAGGACGCCCAGCCC

1401 CCCTGICCTTTCTTTTTCATCGGGCATATGCATGGAAAACGGAGTAACTCCGACCGCAGAAGGCGATCTCTGGAACATGATGCGAGGACGGTGGGTACGA STRE

1501 CATGGCTTTGCATCCGGACAGCGACCAAGCTGCCGGATCCTGTTGGCGCTTGTATAAATAAGCTGGCCGTTTCCCATGCGGCCACCGCTCATCATGCTCI TATA

1601 CCTGGATGAGAAGCATAGAAACCTGACGTCACCAGATAATCTTATCTGTTTATTTTTCACAGAGAAGAAATGGTGCGAACTTCGCTAGCTGCCTTCTCCC

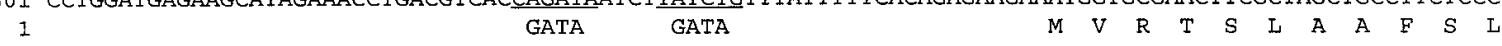

1701 TGGCAGTCGCCGGCCTGGCCAGCGCACAATGCCCCTTCGCAGACCCAGGACGTCTTGCCGCAAGAGCTCAGGGCCTAGATGAATCGTCCAGAGGCCATCT

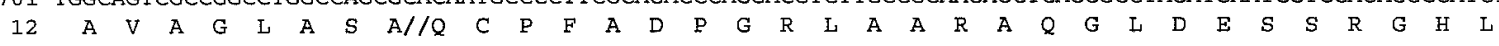

1801 GGCTGGTTTCGAAGTCGACGACAGCGAGGGCTACCTGACGTCCGACGTCGGTGGCCCAATCGAGGATCAGAACAGTCTCAAAGCCGGGGACCGAGGCCCT

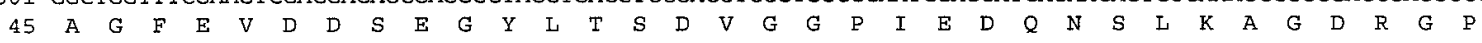

1901 ACACTGCTGGAAGATTTTATTTTCCGACAGAAAATCACCCATTTTGACCACGAGCGAgtaagtgatgaccaggtggaagcgtatgacggtcatggCaggg $\begin{array}{llllllllllllllllllllll}78 & \mathrm{~T} & \mathrm{~L} & \mathrm{~L} & \mathrm{E} & \mathrm{D} & \mathrm{F} & \mathrm{I} & \mathrm{F} & \mathrm{R} & \mathrm{Q} & \mathrm{K} & \mathrm{I} & \mathrm{T} & \mathrm{H} & \mathrm{F} & \mathrm{D} & \mathrm{H} & \mathrm{E} & \mathrm{R}\end{array}$

2001 aataacaagaggctgacacaccgtgtccaacacagGTTCCCGAAAGAGCTGTTCACGCCCGAGGAACAGGCGCCCACGGCACCTTCACCAGCTACGGCGA

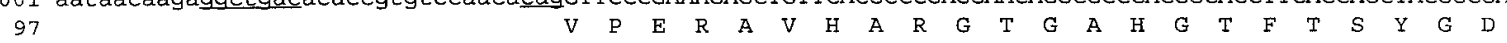

2101 TTATAGCAATATCACCGCAGCCTCATTTTTGGGCCAAAAGGACAAGAAGACGCCCGTATTTGTTCGTTTCTCCACTGTAGCGGGCTCTCGTGGAAGTGCG $\begin{array}{lllllllllllllllllllllllllllllllllll}119 & Y & S & N & I & T & A & A & S & F & L & G & Q & K & D & K & K & T & P & V & F & V & R & F & S & T & V & A & G & S & R & G & S & A\end{array}$

2201 GACACAGCTCGTGACGTGCACGGATTTGCCGTTCGATTgtgagttgatatcatcggcgaccatacactacctaatctagtctcaacggcttgtgagcacg $\begin{array}{lllllllllllllllll}152 & D & T & A & R & D & V & H & G & F & A & V & R & \text { L }\end{array}$

2301 agactgtgatgtgcaagaaagacaatcgtccatgctgaccagtgctgcttcgttgacagGTATACCGACGAAGGAAACTTCGATATCGTGGGCAACAATG 165 $\begin{array}{lllllllllllllllllllllll}Y & T & D & E & G & N & F & D & I & V & G & N & N & V\end{array}$

2401 TTCCTGTGTTCTTCATTCAGGATGCTATCCAATTCCCCGATCTTATCCATTCGGTCAAGCCACGCCAGGACAATGAGATCCCACAGGCTGCCACTGCTCA $\begin{array}{llllllllllllllllllllllllllllllllllllll}179 & P & V & F & F & I & Q & D & A & I & Q & F & P & D & L & I & H & S & V & K & P & R & Q & D & N & E & I & P & Q & A & A & T & A & H\end{array}$

2501 CGACTCAGCGTGGGACTTCTTCTCGCAACAGACGTCGACTCTGCACACTTTGTTCTGGGCCATGGCTGGTTATGGTATCCCACGTAGTTTGCGCCACATG

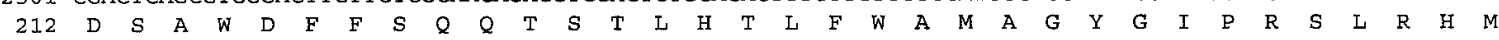

2601 gtacqtcatgcgacacggcttctgatgtcatatgtgctcgtgagattetggagctaattcttgaggacagGACGGTTTTGGTGTACACACATACCGACTC 245 $\begin{array}{llllllllll}D & G & F & G & V & H & T & Y & R & I\end{array}$

2701 GTTACCGATGATGGCACGTCCAAGCTGGTAAAGTGGCACTGGAAGTCTAAGCAGGGCAAAGCCAGTCTAGTTTGGGATGAGGCCCAGCGCGCCGCCGGCA

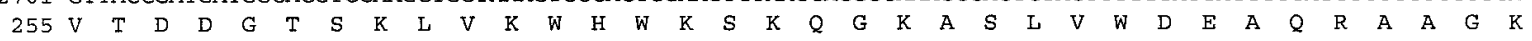
2801 AGAATGCCGACTACCACAGACAGGATCTCTTCGACGCCATCCAGTCGGGCAACTATCCCGAGTGGGAGCTCAACCTGCAAATCATCAACGAGGATCAAGC

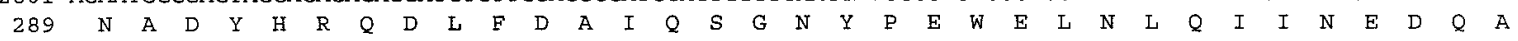

(continued on next page)

Fig. 2. Nucleotide sequence and derived amino acid sequence of the cpcat1 gene of Claviceps purpurea. Putative binding sites for regulatory proteins, TATA box, CAAT sequences, and putative polyadenylation site are underlined, and their characteristics are indicated. Intron consensus sequences are underlined. Putative N-glycosylation sites are printed in bold. // indicates the putative signal peptidase cleavage site. The nucleotide sequence data are available from the EMBL data base (accession number AJ001386). 
main of known catalases. Exhaustive restriction analysis of phage DNA from these clones allowed the identification of a 6.5-kb KpnI fragment consisting of the whole gene, which was named cpcat1. This fragment was subcloned into pUC19, giving the plasmid pcpcat1; its restriction map is shown in Figure 1A. Sequence analysis of the 6.5-kb KpnI fragment showed the presence of an open reading frame (ORF) of 2,148 bp interrupted by five introns (Fig. 2), as predicted by the presence of intron consensus sequences (Ballance 1991) and lack of homology with other catalases. Northern (RNA) blot hybridization with RNA from axenic culture, with the 1.1-kb $\mathrm{SacI}$ fragment from the coding region as a probe, confirmed that this gene is transcribed as an mRNA of $2.4 \mathrm{~kb}$, which is in accordance with the size deduced from the sequence (data not shown). The protein sequence derived from this ORF showed several features characteristic of secreted proteins, including (i) a typical signal peptide (von Heijne 1983) of 19 amino ac- ids, the removal of which would produce a mature protein of 697 amino acids $\left(M_{\mathrm{r}}=76,957\right)$, and (ii) three putative $\mathrm{N}$ linked glycosylation sites (Gavel and von Heijne 1990). Together, these features and the isoelectric point (6.72), as estimated from the amino acid charge, suggested that cpcat 1 codes for either CATC or CATD.

The protein sequence deduced from cpcatl was compared with those from other catalase genes of filamentous fungi. The highest homology was found with Aspergillus nidulans CatB (61.6\% identity) (Kawasaki et al. 1997), with the proteins deduced from three nearly identical Aspergillus fumigatus sequences (61.7\%)—GenBank accession number Y07763 (T. Takasuka, M. Anderson, and D. W. Denning, unpublished), accession number U87850 (D. R. Wysong, R. D. Diamond, and P. W. Robbins, unpublished), and Catl (Calera et al. 1997)—and with A. niger CatR (54.7\%). Interestingly, the predicted peptides from these genes share some characteristics

Fig. 2. (continued from preceding page)

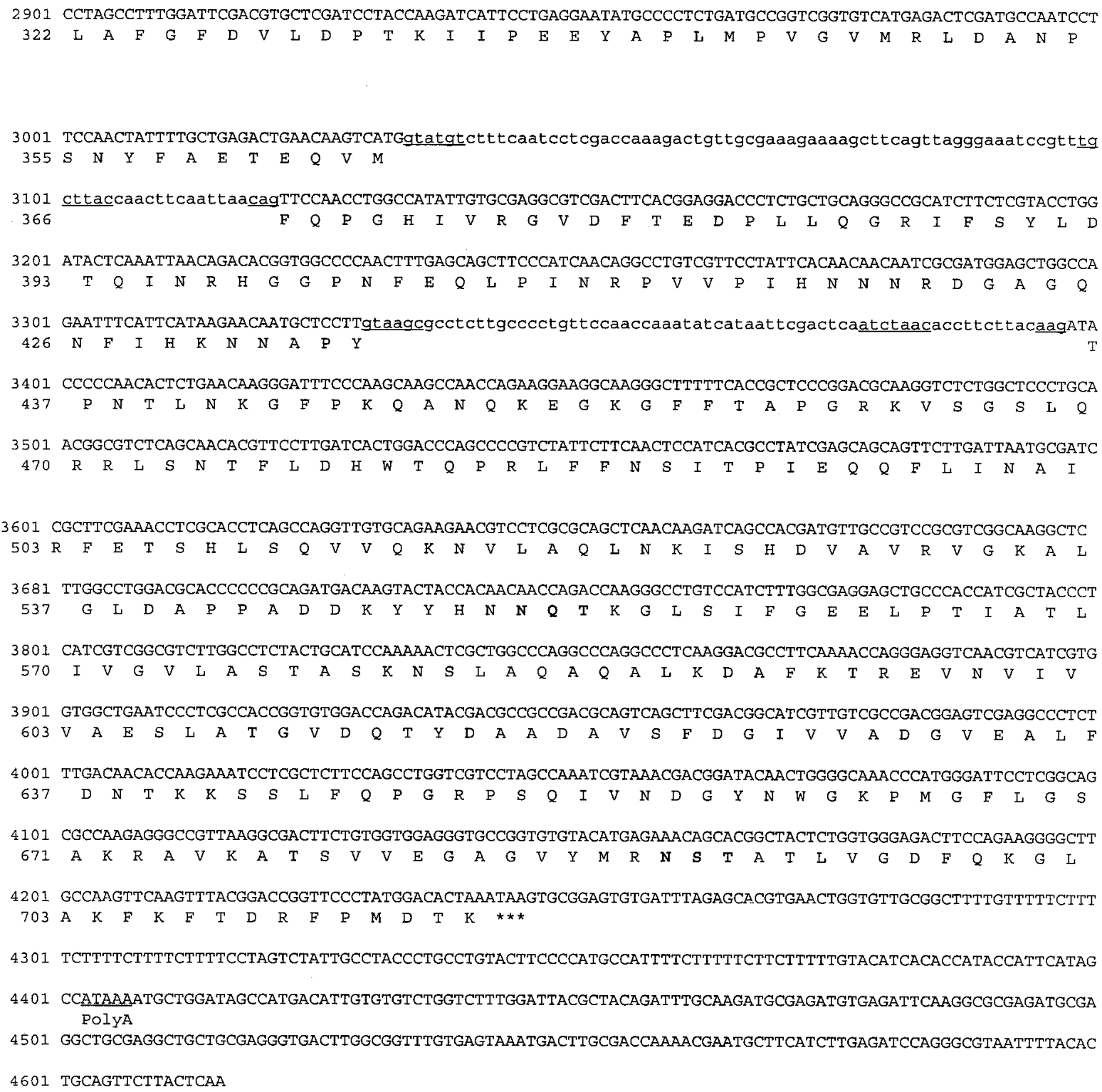


with the protein deduced from cpcatl, such as a putative signal sequence and $\mathrm{N}$-linked glycosylation sites at the same positions in two of the three sites found in the $C$. purpurea protein. Moreover, the positions of the first and third intron in cpcatl are precisely conserved in all of the genes referred to above, despite the presence of additional introns in every case. In contrast, A. nidulans CatA (Navarro et al. 1996), a second A. fumigatus catalase deduced from sequence AFU87630 (GenBank accession number U87630; D. R. Wysong, R. D. Diamond, and P. W. Robbins, unpublished) and Botrytis cinerea CatA (Van der Vlugt-Bergmans et al. 1997) showed only low homology (less than $38 \%$ identity) with the sequence deduced from the cpcatl gene. In addition, they do not have a putative signal sequence. This comparison supports the idea that the protein encoded by cpcatl is a secreted catalase.

Analysis of the upstream noncoding sequence of cpcat1 (Fig. 2) showed typical fungal promoter elements, such as a TATA box and several CAAT sequences, as well as putative binding sites for regulatory proteins whose role in the expression of cpcatl is unknown. An abbreviated form (5'-ATAAA$\left.3^{\prime}\right)$ of the consensus polyadenylation signal in higher eukaryotic organisms was found $157 \mathrm{bp}$ downstream of the stop codon.

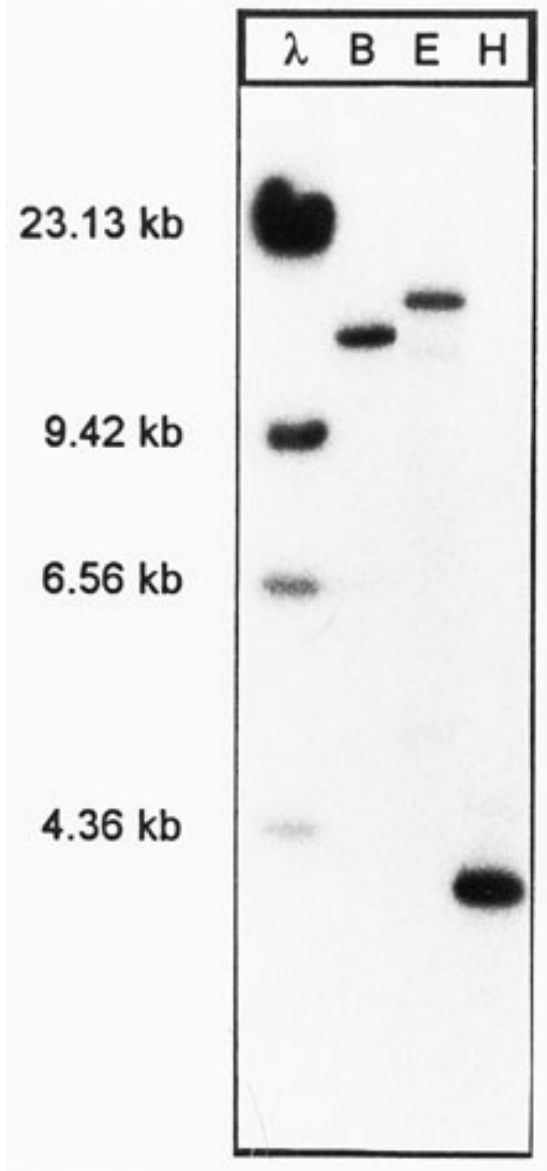

Fig. 3. Determination of the copy number of cpcat1 in strain T5 of Claviceps purpurea. A blot containing lambda DNA digested with HindIII $(\lambda)$ as DNA size marker and genomic DNA of strain T5 digested with BamHI (B), EcoRI (E), or HindIII (H) was simultaneously hybridized with a ${ }^{32} \mathrm{P}$-labeled, 1.1-kb SacI fragment containing part of the cpcat 1 coding region (Fig. 1A) and ${ }^{32} \mathrm{P}$-labeled lambda DNA. Sizes of the lambda HindIII fragments are indicated on left side of figure.
To determine the copy number of cpcatl in the genome of C. purpurea, a genomic Southern blot containing T5 DNA digested with BamHI, EcoRI, and HindIII was hybridized with a probe consisting of a central part of the coding region of cpcat1 (Fig. 1A). Only one strong hybridizing fragment appeared in each lane, indicating that there is only one copy of cpcatl in the genome of $C$. purpurea (Fig. 3). Weaker fragments appeared in every lane, suggesting that there are additional catalase genes with some homology to the cpcatl gene.

\section{Construction and characterization of deletion mutants.}

In order to determine if cpcat 1 codes for the secreted catalase CATD, cpcatl was knocked out in strain 20.1, a haploid derivative of the field isolate T5 (Müller 1997). For construction of the replacement vector pcp $\Delta$ cat1, a $0.3-\mathrm{kb}$ SalI-HindIII fragment from the central part of cpcat1 (in plasmid pcpcat1) was replaced by a phleomycin resistance cassette from plasmid pAN8-1 (Mattern et al. 1988) to produce a nonfunctional cpcat1 allele (Fig. 1B). A 9.4-kb KpnI fragment containing the cpcat $1::$ Phleo $^{\mathrm{r}}$ construct was used to transform strain 20.1. In order to detect homologous integration of the replacement fragment, 112 phleomycin-resistant transformants were selected and analyzed by Southern blot hybridization. Figure 1B shows the event expected upon recombination between the 9.4-kb KpnI fragment and the wild-type allele in the genome. After restriction of genomic DNA from the transformants with $K p n \mathrm{I}$ and hybridization with the 9.4-kb KpnI fragment, four transformants, MS54, MS63, MS80, and MS99, showed only the expected 9.4-kb KpnI fragment (Fig. 4), indicating that the wild-type allele of cpcatl was replaced by the nonfunctional allele used in the transformation. The viability of these transformants showed that the cpcatl gene is nonessential for growth of $C$. purpurea in axenic culture. The remaining transformants showed the wild-type 6.5-kb $K p n I$ fragment and an additional fragment corresponding to an ectopic integration of

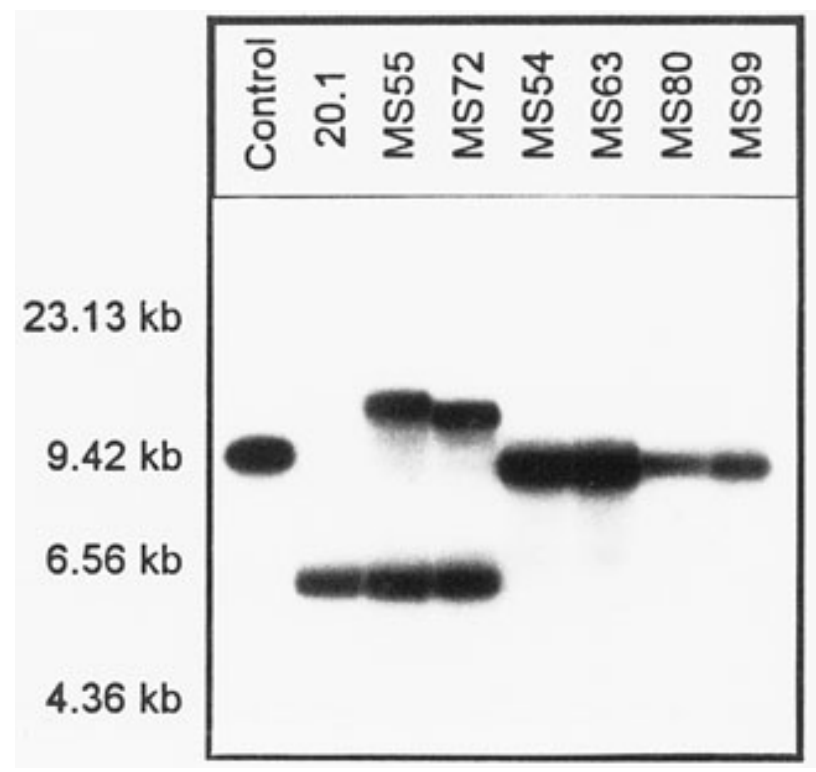

Fig. 4. Southern blot hybridization of transformants of strain 20.1 with pcp $\Delta$ cat 1 containing the desired integration event. A blot containing genomic DNA, digested with $K p n \mathrm{I}$, from the strains indicated in the figure and a control lane with $1.6 \mathrm{ng}$ of purified, 9.4-kb KpnI fragment (Fig. 1B) was hybridized with the same ${ }^{32} \mathrm{P}$-labeled fragment. 
the replacement fragment in the genome of $C$. purpurea. Two of these transformants, MS55 and MS72, having an ectopic integration of the replacement fragment and showing a standard growth rate, were selected for further experiments. To characterize the catalases of strains MS54, MS63, MS80, and MS99, they were grown under conditions in which the wild type produces low amounts of CATD (Mantle medium with reduced sugar content; Garre et al. 1998). The ectopic transformants MS55 and MS72 and the haploidized wild type 20.1 were cultivated identically as controls. Protein extracts from the culture medium of strains carrying the nonfunctional allele of the cpcat 1 gene showed a dramatic reduction (on average around 85-fold) of the total catalase activity (Table 1). A reduction of the catalase activity was also visible in mycelial protein preparations, although less pronounced (around fivefold); the residual activity is probably due to the presence of the intracellular catalase CATA (Table 1). The levels of catalase activity in protein extracts from all strains having a functional cpcat1 gene showed no drastic differences. Isoelectric focusing (IEF) gels of mycelial proteins and subsequent staining for catalase activity revealed that the activity band corresponding to both CATD and CATC was absent in protein preparations from strains MS54, MS63, MS80, and MS99, whereas protein preparations from strains having the wildtype cpcat 1 allele exhibited this activity band (Fig. 5). Due to the difficulty of distinguishing between CATC and CATD in IEF gels, culture medium proteins from all strains were analyzed with cationic native polyacrylamide gel electrophoresis (PAGE), which enhances the mobility differences between CATC and CATD (Garre et al. 1998). Although the protein preparations from strains carrying the wild-type cpcatl allele showed both CATC and CATD, indicating that the growth conditions were adequate for the synthesis of these proteins, similar analysis of strains carrying the nonfunctional allele showed neither CATC nor CATD (data not shown). Activity staining of protein extracts from the strains MS54, MS63, MS80, and MS99 showed normal levels of CATA and CATB (Fig. 5). These data confirm that these mutants lack CATD and CATC as a consequence of the disruption of cpcatl, strongly suggesting that both proteins are encoded by cpcatl. The different mobility of two catalase isoforms encoded by cpcatl in cationic native PAGE could indicate variations in postranslational processing.

\section{Expression of cpcat1 in planta.}

Due to the difficulty in extracting high amounts of mRNA from infected rye ovaries, the presence of cpcat 1 mRNA during infection was studied by means of reverse transcription-

Table 1. Catalase-specific activity of transformants ${ }^{\mathrm{a}}$

\begin{tabular}{lcccc}
\hline Strain & Culture medium & Mycelium & Honeydew & Stage 2 \\
\hline 20.1 & 7.71 & 0.38 & 1.87 & 2.44 \\
MS55 & 8.19 & 0.50 & 3.23 & 1.60 \\
MS72 & 10.41 & 0.41 & 3.37 & $\mathrm{NM}^{\mathrm{b}}$ \\
MS54 & 0.13 & 0.06 & $\mathrm{ND}^{\mathrm{c}}$ & $\mathrm{NM}$ \\
MS63 & 0.13 & 0.11 & $\mathrm{ND}$ & 0.44 \\
MS80 & 0.09 & 0.07 & $\mathrm{ND}$ & $\mathrm{NM}$ \\
MS99 & 0.06 & 0.09 & $\mathrm{ND}$ & 0.14 \\
\hline
\end{tabular}

${ }^{\mathrm{a}}$ Specific activity $=\mathrm{nkat} \cdot \mu \mathrm{g}^{-1}$ protein

b Not measured.

${ }^{\mathrm{c}}$ Not detectable (less than $0.008 \mathrm{nkat} \cdot \mu \mathrm{g}^{-1}$ protein). polymerase chain reaction (RT-PCR). A coding region of cpcat1 containing two introns was selected for amplification with primers P1 and P2 (Fig. 1A). The presence of intron sequences between the primer target sequences enabled the RNA-derived PCR products to be distinguished from the larger, intron-containing PCR products arising from DNA contamination. Rye florets were inoculated with conidia of $C$. purpurea wild-type strain T5. RNA from infected ovaries at previously defined stages of infection constituting the whole infection process (Tenberge et al. 1996) was amplified with the primers P1 and P2. A PCR product of the expected size (474 bp) was found in all stages (Fig. 6A), indicating that this gene is transcribed throughout the entire infection. That the low level of amplification in the sample from stage 1 is probably due to the low amount of fungal RNA in the sample is shown by the similar results of a control PCR, with primers specific for the gpdl gene (Jungehülsing et al. 1994; data not shown). The identity of the RT-PCR product was confirmed by Southern blot analysis with a 1.1-kb $\mathrm{SacI}$ fragment from the coding region of cpcatl as a probe (Fig. 6B).

Protein preparations from all stages of infection were analyzed with IEF and subsequent catalase staining. The activity band corresponding to CATC/CATD was present from the start of the infection throughout the entire infection (Fig. 7). The protein preparation from stage 1 ( 5 days after inoculation) also showed rye catalase; this indicates that either both catalases are present in the same ovary or that the sample contained noninfected ovaries. In order to distinguish between the isozymes CATC and CATD, the protein preparations were analyzed with cationic native PAGE; only CATD was present (data not shown). This presence of CATD during the early stages of infection would be in accordance with a role in the destruction of $\mathrm{H}_{2} \mathrm{O}_{2}$ generated during the plant defense response.

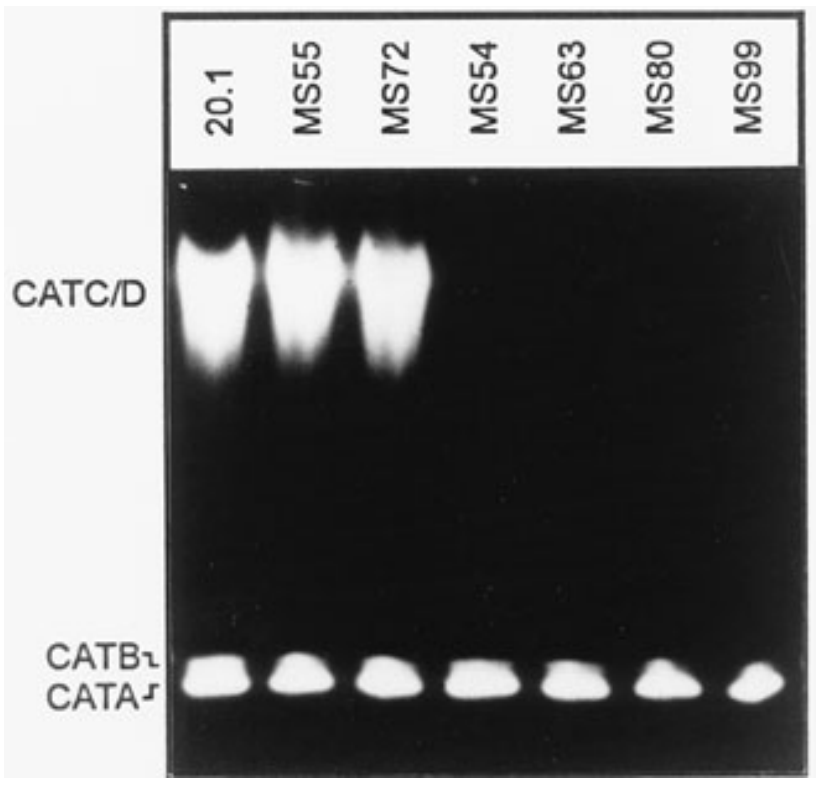

Fig. 5. Analysis of catalase isoforms present in the mycelium of transformants. Protein extracts were prepared from 5-day-old mycelia grown in Mantle medium with low glucose content (Brockmann et al. 1992). In every lane of an isoelectric focusing (IEF) gel with a $\mathrm{pH}$ range from 5 (bottom) to 8 (top), $2.5 \mu \mathrm{g}$ of protein was loaded. After electrophoresis, the gel was stained for catalase activity. 
Pathogenicity of cpcat1 mutants.

The pathogenicity of the four independently obtained cpcat1 mutants was compared with that of strains MS55 and MS72 and the wild-type strain 20.1, which was used as a recipient in the transformation. Ears from healthy plants were inoculated with conidia from all strains, and parameters defining the extent of the infection were analyzed (Table 2). Ears inoculated with both the conidia of mutants and those of wildtype strains showed a similar level of infection. There were no significant differences in the time it took to produce honeydew, the amount of honeydew produced, or the formation of sclerotia. Southern analysis of KpnI-digested genomic DNA isolated from germinated conidia of honeydew confirmed that the infection was caused by cpcatl mutants (data not shown).

To characterize the infection carried out by the cpcatl mutants, the catalase activity in honeydew was measured (Table 1). As expected, no catalase activity was found, confirming that the catalase secreted during the infection is the protein CATD encoded by the cpcatl gene of $C$. purpurea and therefore is not of plant origin. A decrease of the catalase activity in ovaries infected with the cpcat1 mutants MS63 and MS99 was also evident, although less pronounced, probably due to the presence of CATA and CATB (see below). In ovaries infected with MS63 and MS69 (harvested at stages 1 and 2 of infection) only the fungal catalases CATA and CATB could be detected, whereas ovaries infected with the wild-type strain showed also CATD (see Figure 8). These data confirm that the major catalase of ovaries infected with wild-type strains is indeed CATD and that this catalase is not essential for the virulence of $C$. purpurea.

\section{DISCUSSION}

Using the catR gene of $A$. niger as a probe, we have cloned a gene, cpcatl, that shows homology to bacterial and fungal catalases. Using a gene replacement approach, we have cre-

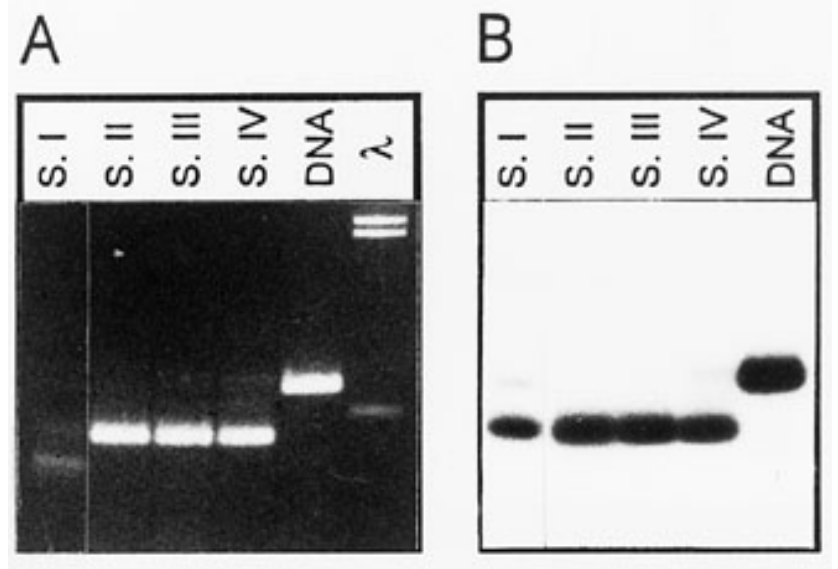

Fig. 6. Expression analysis of cpcat1. A, Reverse-transcriptionpolymerase chain reaction (RT-PCR) with RNA from different stages of infection (S.I: stage 1; S.II: stage 2; S.III: stage 3; and S.IV: stage 4) with primers P1 and P2 (Fig. 1A). As a control, genomic DNA was amplified by PCR with the same primers. Only size markers of 2.32, 2.03, and $0.56 \mathrm{~kb}$ (from top to bottom) from lambda DNA digested with HindIII (lane $\lambda$ ) are shown. B, Gel from $\mathbf{A}$ was blotted and hybridized with the 1.1-kb $S a c$ I fragment as probe (Fig. 1A). Lane S.I was exposed three times longer than the other lanes. ated deletion mutants of cpcat1. Analysis of protein extracts of the mutants grown in axenic culture indicated that CATC and CATD are both encoded by cpcat 1 ; they probably vary in their degree and/or kind of posttranscriptional modification. Given that the protein sequence has three putative $\mathrm{N}$ glycosylation sites, it would be possible to attribute the isoforms to differing glycosylation levels. Glycosylation in catalases has been previously reported for a secreted catalase of Penicillium chrysogenum (Chaga et al. 1992), for CAT1 from A. fumigatus (López-Medrano et al. 1995), for a Penicillium vitale catalase (Gudkova et al. 1985), and for catalases from A. niger (Wasserman and Hultin 1981; Kikuchi-Torii et al. 1982). In the latter case, the presence of covalently bound

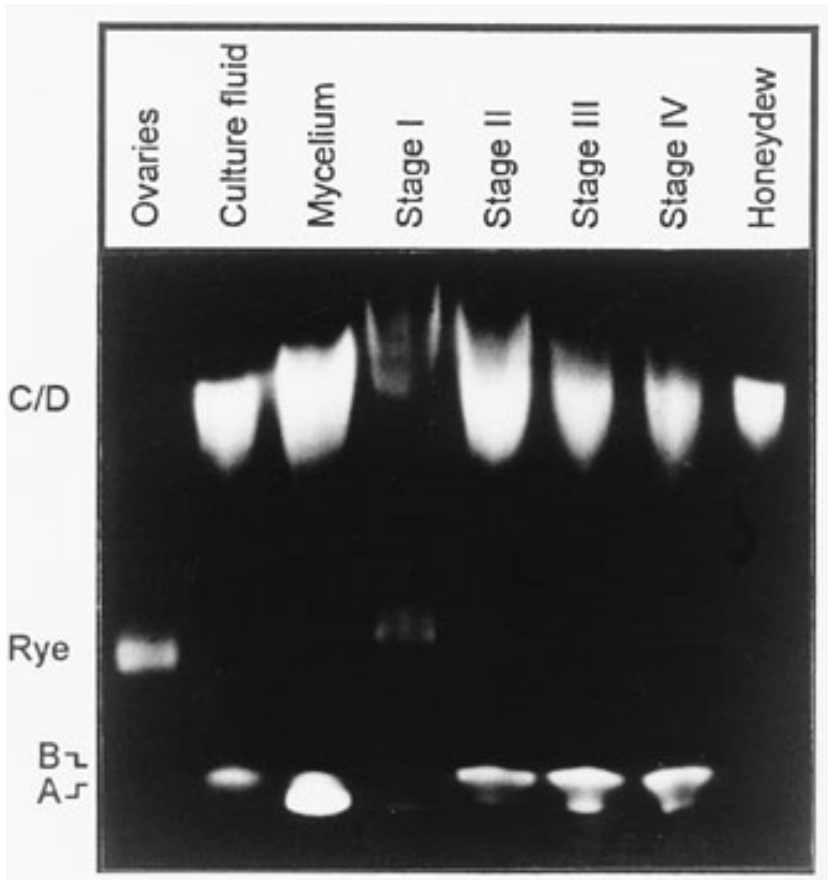

Fig. 7. Detection of catalases during parasitic growth of Claviceps purpurea on rye. Proteins prepared from ovaries infected with the wild-type strain T5 (stages 1 to 4), from exuded honeydew, noninfected ovaries (lane ovaries), from mycelium grown for 5 days in Mantle medium with reduced sugar content (lane mycelium), and from the corresponding culture medium (culture fluid) were applied to an isoelectric focusing (IEF) gel with a $\mathrm{pH}$ range from 5 (bottom) to 8 (top). After electrophoresis, the gel was stained for catalase activity. Approximately the same catalase activity $(\approx 20$ nkat) was applied to every lane, with the exception of stage 1 (<10 nkat), which contains only very limited fungal biomass.

Table 2. Infection parameters

\begin{tabular}{lccccc}
\hline Strain & $\begin{array}{c}\text { Germin- } \\
\text { ation rate } \\
(\%)\end{array}$ & $\begin{array}{c}\text { Ears } \\
(\mathbf{n o})\end{array}$ & $\begin{array}{c}\text { Start of } \\
\text { Honeydew } \\
\left(\mathbf{d p i}^{\mathrm{a}}\right)\end{array}$ & $\begin{array}{c}\text { Amount } \\
\text { of Honey- } \\
\text { dew }\end{array}$ & $\begin{array}{c}\text { Sclerotium } \\
\text { formation } \\
(\%)\end{array}$ \\
\hline 20.1 & 94.5 & 3 & 6.0 & +++ & 68 \\
MS55 & 43.5 & 4 & 6.0 & +++ & 59 \\
MS72 & 48.0 & 4 & 6.0 & +++ & $\mathrm{ND}^{\mathrm{b}}$ \\
MS54 & 56.5 & 5 & 6.6 & +++ & 64 \\
MS63 & 61.0 & 6 & 6.2 & +++ & 63 \\
MS80 & 53.0 & 5 & 6.2 & +++ & ND \\
MS99 & 82.5 & 5 & 5.6 & +++ & 71 \\
\hline
\end{tabular}

${ }^{a}$ Days post infection.

b Not determined. 
sugars enhances the stability of $A$. niger catalase (Wasserman and Hultin 1981). Furthermore, the A. niger catalase appears in three isoforms. Two of them are characterized by the presence of extra sugars bound noncovalently to the smallest form (Kikuchi-Torii et al. 1982).

The protein encoded by cpcat1, CPCAT1 (= CATC/D), belongs to a class of catalases with characteristics of secreted proteins, which are grouped together in a tree analysis (Fig. 9), indicating a common ancestor. The subcellular localization of proteins belonging to this group has been preliminarily described for CAT1 from A. fumigatus and A. niger CatR. CAT1 seems to be extracellular (Calera et al. 1997) and CatR is probably a cell-wall-associated protein; under the growth conditions used by Fowler et al. (1993), more than $90 \%$ of catalase activity is cell associated. This assumption is further supported by the identification of cell-wall-associated catalases in A. niger (Witteveen et al. 1992). This could mean that extracellular catalases in A. niger are normally cell wall associated and under certain conditions can be released into the medium. Our earlier observations (Garre et al. 1998) indicate that CATB of $C$. purpurea could be such a cell-wall-associated enzyme, since, in contrast to CATC/D, the enzyme is only rarely found in the culture medium. The different catalase isoforms are differentially regulated in some fungi, e.g., in $A$. nidulans, and are thought to belong to the cellular defense mechanism against general oxidative stress and during differ- entiation (conidiation, etc.). Preliminary Northern experiments indicate that expression of cpcatl in axenic culture is induced by stress, e.g., any medium transfer leads to expression of cpcatl within $1 \mathrm{~h}$ (data not shown). As shown in Figure 2, the promoter of cpcat 1 contains a stress-response element (STRE) that plays a crucial role in the stress control of yeast genes, including CTT1, which encodes a cytosolic catalase (Schüller et al. 1994).

For a pathogenic fungus such as $C$. purpurea, the colonization of plant tissue must surely be accompanied by stress, especially if part of the plant defense response includes production of active oxygen species (AOS). Therefore, fungal catalases could play a role in self-defense of the fungus; secreted catalases could even interfere with the plant's defense mechanism. In accordance with this idea, all major fungal catalases (CATA, B, D) are found in infected tissue. Furthermore, CATD is even found in honeydew of infected plants, and cpcat 1 is expressed throughout the entire infection cycle. Nevertheless, deletion of cpcat1, i.e., loss of the major secreted catalase form, does not impair the parasitic properties of $C$. purpurea, as judged from timing and amount of honeydew and sclerotia production. Several explanations are possible. First, either $\mathrm{H}_{2} \mathrm{O}_{2}$ is not required for triggering the plant defense response in rye, or it is not produced during the infection. Oxalate crystals have been found at the ergot-rye interface (Tudzynski et al. 1995; A. Hambrock, K. B. Tenberge,

\section{Stage I}

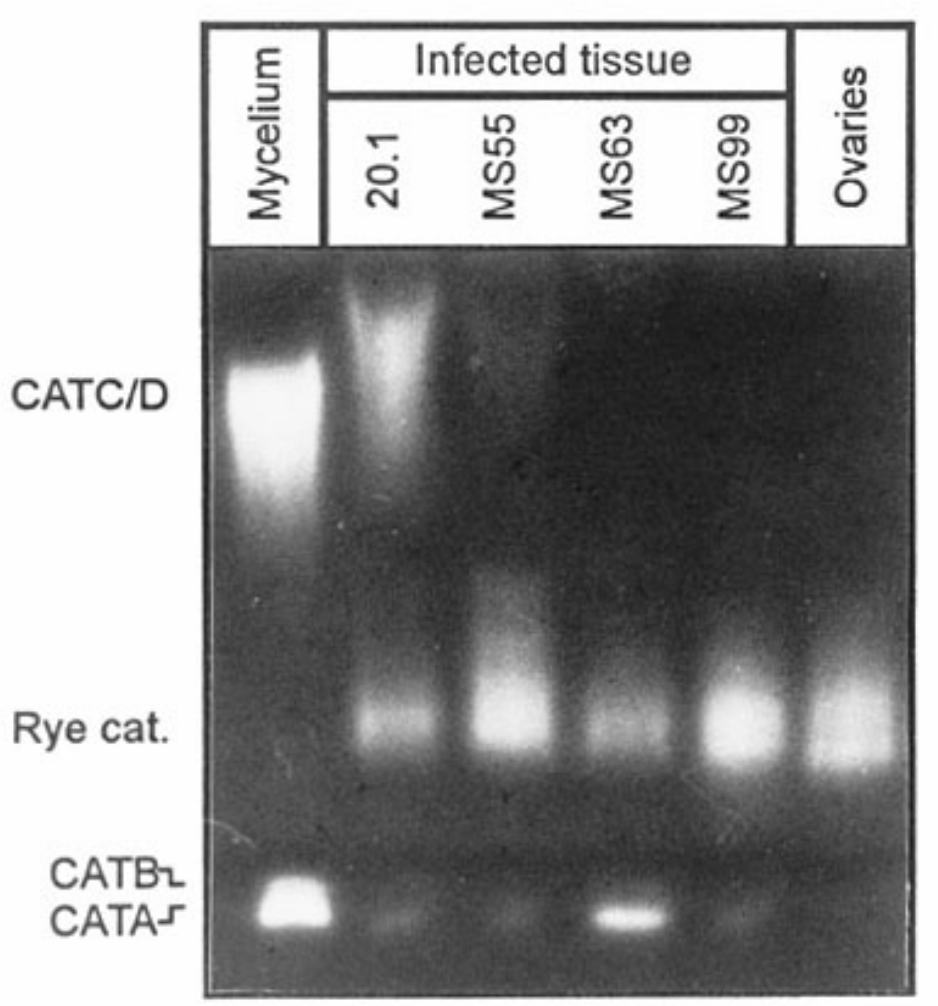

\section{Stage II}

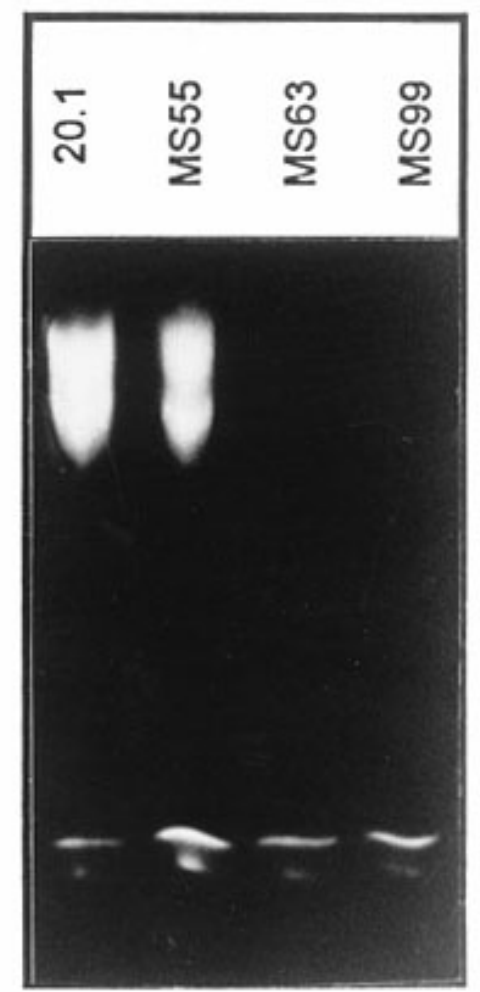

Fig. 8. Detection of catalases in ovaries infected by cpcat1 mutants. Protein prepared from ovaries infected with the wild-type strain 20.1 , MS55 and mutants MS63 and MS99 at stages 1 and 2 was applied to an isoelectric focusing (IEF) gel with a pH range from 5 (bottom) to 8 (top). As controls, a lane containing noninfected ovary proteins (lane ovaries) and a lane containing proteins from 5-day-old mycelium grown in Mantle medium with reduced sugar content (lane mycelium) were included. Approximately the same protein amount was applied in the samples from stage 1 ( $24 \mu \mathrm{g})$, and stage $2(12 \mu \mathrm{g})$, except in the control lane with mycelial proteins $(76.8 \mu \mathrm{g})$ and noninfected ovary proteins $(22 \mu \mathrm{g})$. 
and P. Tudzynski, unpublished). Oxalate may act as a substrate for an assumed oxalate oxidase in rye, thus contributing to the generation of $\mathrm{H}_{2} \mathrm{O}_{2}$ (Dumas et al. 1995; Zhang et al. 1995). $\mathrm{H}_{2} \mathrm{O}_{2}$ production by rye is further supported by the detection of peroxidase activity, accumulation of polyphenolics, and lignification at the persistent colonization barrier of ergot in the rye rachilla (Hambrock 1996). Second, an additional catalase (e.g., CATB) could compensate for the loss of CATD in the deletion mutants. Although cpcatl mutants lack CATD and CATC, they have normal levels of CATB in axenic culture; in addition, CATB is found in rye tissue infected with cpcatl mutants, though in stage 1 in traces only (Fig. 8). Third, the pathogenicity test may not be sensitive enough. If it has a role in detoxifying AOS, the function of a catalase should be of highest importance during the initial stage of infection, and an artificial inoculation could produce a cooperative infection that, especially in the first stages, differs from the natural infection process (e.g., by high spore titers).
CPCAT1 is the first catalase of a plant-pathogenic fungus that has been shown to be secreted in planta. The only other example of a functional analysis of a secreted fungal catalase comes from a human pathogen, Aspergillus fumigatus. As in plants, an oxidative burst is involved in human and animal pathogen defense systems (Low and Merida 1996), and a secreted catalase of A. fumigatus has been suggested to be of importance in pathogenesis. In this system as well, knocking out of one of the two catalase genes in A. fumigatus did not have any influence on pathogenicity in a model test system (Calera et al. 1997). Obviously, the complexity of AOSdetoxifying systems is such that deletion of one component does not result in drastic changes. A detailed cytological analysis of plant tissue infected with the cpcatl mutants will clarify if there is still catalase activity around the hyphae, as indicated by the biochemical analyses (see Figure 8). If this is the case, then another cell-wall-associated (or secreted) catalase could be involved; as outlined above, the best candidate

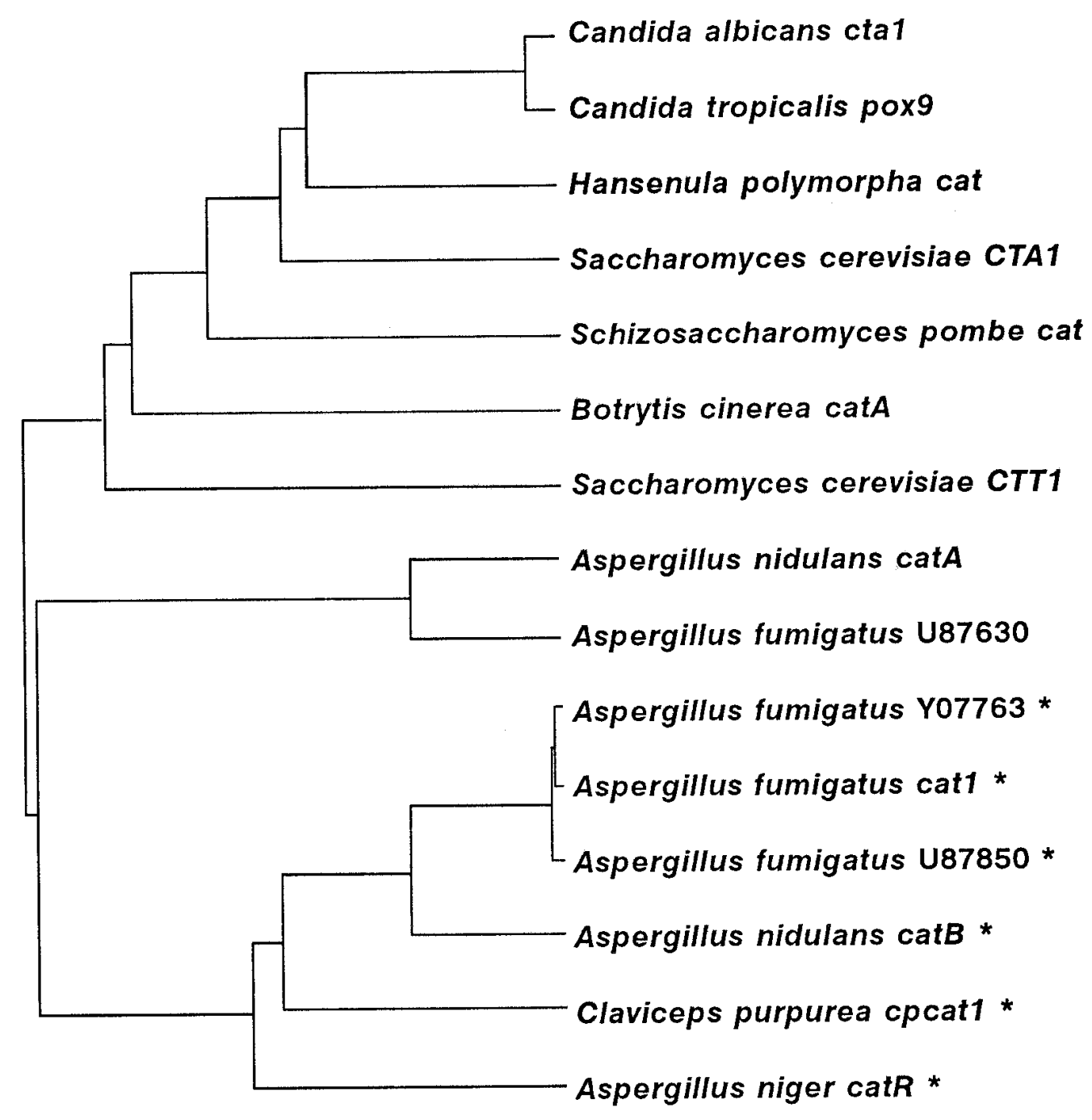

Fig. 9. Tree analysis of fungal catalases based on derived amino acid sequences from Candida albicans cta1: accession number AB006327 (Nakagawa et al. 1995); Candida tropicalis pox9: Okada et al. (1987); Hansenula polymorpha cat: Didion and Roggenkamp (1992); Saccharomyces cerevisiae CTA1: Cohen et al. (1988); Saccharomyces cerevisiae CTT1: Hartig and Ruis (1986); Schizosaccharomyces pombe cat: Nakagawa et al. (1995); Botrytis cinerea catA: Van der Vlugt-Bergmans et al. (1997); Aspergillus nidulans catA: Navarro et al. (1996); Aspergillus nidulans catB: Kawasaki et al. (1997); Aspergillus fumigatus cat1: Calera et al. (1997); Aspergillus niger catR: Fowler et al. (1993). Secreted/cell-wall-associated catalases are marked by an asterisk. 
for such a protein is CATB. Therefore, the next step in analyzing the importance of AOS detoxification in the interaction of $C$. purpurea and rye will be the cloning and functional analysis of the gene coding for CATB. Furthermore, investigation of other enzymes involved in the detoxification of AOS, such as peroxidases and superoxide dismutases, may be crucial for a good understanding of this subject.

\section{MATERIALS AND METHODS}

\section{Strains and culture conditions.}

C. purpurea strains used in this work were strain T5, a standard field isolate of $C$. purpurea (Fr.:Fr.) Tul., isolated from rye (Secale cereale L.; Hohenheim, Germany), and strain 20.1, a putative haploid derivative from strain T5 obtained by treatment with benomyl (Müller 1997). Mycelia were routinely grown at $28^{\circ} \mathrm{C}$ on complete medium (BII) (Esser and Tudzynski 1978) for maintenance and DNA isolation, or Mantle medium for conidia harvesting (Mantle and Nisbet 1976). For protein and RNA isolation, three colonies grown on solid Mantle medium were cut into small pieces, and then cultivated in $100 \mathrm{ml}$ (Erlenmeyer flasks of 300-ml capacity) of Mantle medium with reduced sugar content (1\% glucose) on a G25 rotary shaker (New Brunswick Scientific, Edison, NJ) at $150 \mathrm{rpm}$ for 5 days at $28^{\circ} \mathrm{C}$.

Escherichia coli strain DH5 $\alpha$ (Hanahan 1983) was used for all the subcloning experiments, and strain K803 (Wood 1996) was employed for propagation of $C$. purpurea genomic lambda clones.

\section{Parasitic culture on rye plants.}

Rye plants were cultivated in growth chambers as described by Smit and Tudzynski (1992), and inoculated with $10 \mu \mathrm{l}$ of solution containing $10^{4}$ conidia collected from Mantle plates as described elsewhere (Tenberge et al. 1996).

\section{Preparation of protein extracts.}

Liquid cultures were filtered (filter type 595; Schleicher \& Schuell, Dassel, Germany) to separate mycelium from culture medium. Mycelial proteins were prepared from frozen mycelium ground with a mortar and pestle. Ground mycelium was suspended in double-distilled water and used directly. Culture fluid and honeydew were dialyzed against double-distilled water and used directly or after concentration by lyophilization. Proteins from infected and noninfected rye ovaries were prepared as previously described for rye leaf tissues (Feierabend et al. 1992).

\section{Catalase activity assay and protein concentration determination.}

Catalase (EC 1.11.1.6) activity was determined spectrophotometrically by measuring the decomposition of $\mathrm{H}_{2} \mathrm{O}_{2}$ at $230 \mathrm{~nm}$ (Eising and Gehardt 1986). Protein concentration was determined according to Bradford (1976).

\section{Gel electrophoresis and catalase activity staining.}

Native IEF was performed in a 1.5 -mm-thick vertical slab minigel system as previously described (Robertson et al. 1987) with carrier ampholytes from $\mathrm{pH} 8$ to 5. Samples containing $30 \mathrm{mM}$ dithioerythritol (DTE), 30\% (vol/vol) glycerol, and $2 \%(\mathrm{vol} / \mathrm{vol})$ ampholytes $\mathrm{pH} 3$ to 10 were applied to the gel and electrophoresed for $90 \mathrm{~min}$ at $200 \mathrm{~V}$ and $150 \mathrm{~min}$ at $400 \mathrm{~V}$. Native cationic PAGE was performed in a minigel system containing $7.5 \%$ (wt/vol) acrylamide, as previously described (Brockmann et al. 1992). After electrophoresis, gels were stained for catalase activity (Clare et al. 1984).

\section{Disruption of cpcat1.}

As a prerequisite for the inactivation of cpcatl, the gene was disrupted in vitro by substitution of an internal $0.3-\mathrm{kb}$ HindIII-SalI fragment with a phleomycin resistance cassette. The replacement fragment for cpcatl was constructed in two steps, employing two plasmids derived from phages containing the cpcatl gene (Fig. 1B). The 3.2-kb EcoRI-XbaI fragment bearing the phleomycin resistance cassette was isolated from plasmid pAN8-1 and introduced into EcoRI-XbaI sites of the pUC19 polycloning site of a plasmid carrying a 5-kb SalI fragment that contained the $3^{\prime}$ region of cpcatl beyond the KpnI site (see Figure 1A). In the next step, the $5^{\prime}$ part of the gene, extending from the HindIII site (at the middle of the gene) to a BamHI site upstream of the KpnI site, was purified from a second plasmid by restriction with BamHI and HindIII, and afterwards cloned, in the correct orientation, into the $B g l \mathrm{II}$ site of the phleomycin resistance cassette (Fig. 1B), yielding the plasmid $\mathrm{pcp} \Delta \mathrm{cat} 1$. The replacement fragment was released by restricting pcp $\Delta$ cat 1 with $K p n I$ and purified by agarose gel electrophoresis. After staining with ethidium bromide, the corresponding 9.4-kb KpnI fragment was excised and then eluted with the Biotrab-Electroseparation system according to the supplier's instructions (Schleicher \& Schuell, Dassel, Germany). Protoplasts from strain 20.1, generated with Novozym 234 (Novo, Bagsvaerd, Denmark), were transformed with 10 $\mu \mathrm{g}$ of the 9.4-kb KpnI fragment as described by Jungehülsing et al. (1994).

\section{Nucleic acid manipulation and analysis.}

Standard recombinant DNA methods were performed according to Sambrook et al. (1989) and Ausubel et al. (1987). Genomic DNA of $C$. purpurea was prepared from lyophilized mycelium according to Cenis (1992). RNA for expression analysis during the parasitic cycle of ergot was prepared according to Chambers and Russo (1986) as described previously (Müller et al. 1997). RNA from axenic culture was isolated from lyophilized mycelium with Trizol reagent according to the supplier (Gibco, Eggenstein, Germany).

For Southern blot analysis, restricted chromosomal DNA (5 to $10 \mu \mathrm{g}$ ) or PCR products were electrophoresed in 1 to $2 \%$ agarose gels with Tris-acetate-EDTA buffer (Sambrook et al. 1989), blotted onto positively charged Nylon filters (Hybond$\mathrm{N}^{+}$, Amersham, Braunschweig, Germany), and hybridized to radioactively labeled DNA probes (Feinberg and Vogelstein 1983 ) at $65^{\circ} \mathrm{C}$ (homologous probes) or $60^{\circ} \mathrm{C}$ (heterologous probe) in Denhardt's hybridization solution (Sambrook et al. 1989). For homologous hybridization experiments, filters were washed twice in $2 \times \mathrm{SSC}(1 \times \mathrm{SSC}$ is $0.15 \mathrm{M} \mathrm{NaCl}$ plus $0.015 \mathrm{M}$ sodium citrate), $0.1 \%$ sodium dodecyl sulfate (SDS) at room temperature for $5 \mathrm{~min}$ and twice in $0.1 \times \mathrm{SSC}, 0.1 \%$ SDS at $65^{\circ} \mathrm{C}$ for $15 \mathrm{~min}$. In heterologous hybridization experiments, with the $1.75-\mathrm{kb}$ SalI fragment from the A. niger CatR gene as a probe, filters were washed twice in $2 \times \mathrm{SSC}$, $0.1 \%$ SDS at room temperature for $5 \mathrm{~min}$ and then twice at $60^{\circ} \mathrm{C}$ for $15 \mathrm{~min}$. Northern blot hybridization experiments 
were carried out as previously described (Garre et al. 1994), with 25 to $50 \mu \mathrm{g}$ of total RNA per sample.

For molecular cloning of cpcat1, a genomic EMBL3 library of strain T5 (Smit and Tudzynski 1992) was screened by plaque filter hybridization according to Sambrook et al. (1989) with the $1.75-\mathrm{kb}$ SalI fragment from the A. niger CatR gene as a probe and employing the hybridization conditions described above.

DNA sequencing was carried out with a DNA sequencer from LICOR (model 4000) and the thermo sequenase fluorescent-labeled primer cycle sequencing kit with 7-deaza-dGTP (Amersham, Braunschweig, Germany) together with IRD41labeled primer (MWG, Ebersberg, Germany). Computer analysis of the sequence was performed with HUSAR (EMBL, Heidelberg, Germany). Multiple alignment was carried out with PILEUP (Feng and Doolittle 1987).

For RT-PCR for the cpcatl gene, oligonucleotides P1: 5'GTG ACG TGC ACG GAT TTG-3', and P2: 5'-CGT TGA TGA TTT GCA GGT TG-3', whose target sequences are indicated in Figure 1A, were employed. RT-PCR was carried out as described previously (Müller et al. 1997) with $1 / 10$ part of the RT-reaction. The PCR run started with a first cycle of 4 min at $94^{\circ} \mathrm{C}$, followed by 30 cycles of $1 \mathrm{~min}$ at $61^{\circ} \mathrm{C}, 30 \mathrm{~s}$ at $72^{\circ} \mathrm{C}$, and $1 \mathrm{~min}$ at $94^{\circ} \mathrm{C}$. The PCR was ended with a extension step of $5 \mathrm{~min}$ at $72^{\circ} \mathrm{C}$. RT-PCR for the GPD 1 was done as described by Müller et al. (1997).

\section{ACKNOWLEDGMENTS}

We wish to thank T. Fowler (Genencor International, San Francisco) for providing us with the CatR gene from A. niger; K. B. Tenberge for helpful discussions, B. Oeser for supplying us with RNA from parasitic cultures of $C$. purpurea, S. Moore for critical reading, and A. Kammerahl for typing the manuscript. V. G. gratefully acknowledges a fellowship provided by the European Community within the Human Capital and Mobility network "Molecular Phytopathology" and a short-term fellowship (ASTF 8769) provided by EMBO.

\section{LITERATURE CITED}

Ausubel, F. M., Brent, R., Kingston, R. E., Moore, D. D., Seidmann, J. G., Smith, J. A., and Struhl, K. 1987. Currents Protocols in Molecular Biology. John Wiley \& Sons, New York.

Ballance, D. J. 1991. Transformation systems for filamentous fungi and an overview of fungal gene structure. Pages 1-29 in: Molecular Industrial Mycology: Systems and Applications for Filamentous Fungi. S. A. Leong and R. M. Berka, eds. Marcel Dekker, New York.

Bradford, M. 1976. A rapid and sensitive method for quantitation of microgram quantities of protein utilizing the principle of protein dye binding. Anal. Biochem. 72:248-254.

Bradley, D. J., Kjellbom, P., and Lamb, C. J. 1992. Elicitor- and woundinduced oxidative cross-linking of a proline-rich plant cell wall protein: A novel, rapid defense response. Cell 70:21-30.

Brisson, L. F., Tenhaken, R., and Lamb, C. 1994. Function of oxidative cross-linking of cell wall structural proteins in plant disease resistance. Plant Cell 6:1703-1712.

Brockmann, B., Smit, R., and Tudzynski, P. 1992. Characterization of an extracellular $\beta$-1,3-glucanase of Claviceps purpurea. Physiol. Mol. Plant Pathol. 40:191-201.

Calera, J. A., Paris, S., Monod, M., Hamilton, A. J., Debeaupuis, J. P., Diaquin, M., López-Medrano, R., Leal, F., and Latgé, J. P. 1997. Cloning and disruption of the antigenic catalase gene of Aspergillus fumigatus. Infect. Immun. 65:4718-4724.

Cenis, J. L. 1992. Rapid extraction of fungal DNA for PCR amplification. Nucleic Acids Res. 20:2380.

Chaga, G. S., Medin, A. S., Chaga, S., and Porath, J. O. 1992. Isolation and characterization of catalase from Penicillium chrysogenum. J.
Chromatogr. 604:177-183.

Chambers, A. A., and Russo, V. E. A. 1986. Isolating RNA is easy and fun. Fungal Genet. Newsl. 33:22-23.

Clare, D. A., Duong, M. N., Darr, D., Archibald, F., and Fridovich, I. 1984. Effects of molecular oxygen on detection of superoxide radical with nitroblue tetrazolium and on activity stains for catalase. Anal. Biochem. 140:5332-5337.

Cohen, G., Rapatz, W., and Ruis, H. 1988. Sequence of the Saccharomyces cerevisiae CTA1 gene and amino acid sequence of catalase A derived from it. Eur. J. Biochem. 176:159-163.

Didion, T., and Roggenkamp, R. 1992. Targeting signal of the peroxisomal catalase $\mathrm{n}$ the methylotrophic yeast Hansenula polymorpha. FEBS Lett. 303:113-116.

Doke, N. 1983. Involvement of superoxide anion generation in the hypersensitive response of potato tuber tissues to infection with the incompatible race of Phytophthora infestans and to hyphal cell wall components. Physiol. Plant Pathol. 23:345-357.

Dumas, B., Freyssinet, G., and Pallett, K. E. 1995. Tissue-specific expression of germin-like oxalate oxidase during development and fungal infection of barley seedlings. Plant Physiol. 107:1091-1096.

Eising, R., and Gerhardt, B. 1986. Activity and hematin content of catalase from greening sunflower cotyledons. Phytochemistry 25:2731.

Esser, K., and Tudzynski, P. 1978. Genetics of the ergot fungus Claviceps purpurea. I. Proof of a nomoecious life cycle and segregation patterns for mycelial morphology and alkaloid production. Theor. Appl. Genet. 53:145-149.

Feierabend, J., Schaan, C., and Hertwig, B. 1992. Photoinactivation of catalase occurs under both high- and low-temperature stress conditions and accompanies photoinhibition of photosystem II. Plant Physiol. 100:1554-1561.

Feinberg, A. P., and Vogelstein B. 1983. A technique for radiolabeling DNA restriction endonuclease fragments to high specific activity. Anal. Biochem. 132:6-13.

Feng, D. F., and Doolittle, R. F. 1987. Progressive sequence alignment as a prerequisite to correct phylogenetic trees. J. Mol. Evol. 25:351360.

Fowler, T., Rey, M. W., Vähä-Vahe, P., Power, S. D., and Berka, R. M. 1993. The catR gene encoding a catalase from Aspergillus niger: Primary structure and elevated expression through increased gene copy number and use of a strong promoter. Mol. Microbiol. 9:989-998.

Garre, V., Murillo, F. J., and Torres-Martínez, S. 1994. Isolation of the facA (acetyl-CoA synthetase) gene of Phycomyces blakesleeanus. Mol. Gen. Genet. 244:278-286.

Garre, V., Tenberge, K. B., and Eising, R. 1998. Secretion of a fungal extracellular catalase by Claviceps purpurea during infection of rye: Putative role in pathogenicity and suppression of host defense. Phytopathology 88:744-753.

Gavel, Y., and von Heijne, G. 1990. Sequence differences between glycosylated and non glycosylated Asn-X-Ser/Thr acceptor sites: implications for protein engineering. Protein Eng. 3:433-442.

Gudkova, L. V., Guliy, M. F., Degtjar, R. T., and Pisaverich, O. V. 1985. Study of the subunit structure of catalase from Penicillium vitale. Ukr. Biokhim. Zh. 57:29.

Hambrock, A. 1996. Untersuchungen über pflanzliche Abwehrreactionen bei der Interaction von Claviceps purpurea (Fr.) Tul. mit Secale cereale L. Licht- und elektronenmikroskopische sowie biochemische Analysen. Ph.D. thesis. Westf. Wilhelms-Universität Münster.

Hammond-Kosack, K. E., and Jones, J. D. G. 1996. Resistance genedependent plant defense responses. Plant Cell 8:1773-1791.

Hanahan, D. 1983. Studies on transformation of Escherichia coli with plasmids. J. Mol. Biol. 166:557-563.

Hartig, A., and Ruis, H. 1986. Nucleotide sequence of the Saccharomyces cerevisiae CTT1 gene and deduced amino-acid sequence of yeast catalase T. Eur. J. Biochem. 160: 487-490.

Joosten, M. H. A. J., Cozijensen, A. J., and De Wit, P. J. G. M. 1994. Host resistance to a fungal tomato pathogen lost by a single base-pair change in avirulence gene. Nature 367:384-387.

Jungehülsing, U., Arntz, C., Smit, R., and Tudzynski, P. 1994. The Claviceps purpurea glyceraldehyde-3-phospate dehydrogenase gene: Cloning, characterization, and use for the improvement of a dominant selection system. Curr. Genet. 25:101-106.

Katsuwon, J., and, Anderson, A. J. 1990. Catalase and superoxide dis- 
mutase of root-colonizing saprophytic fluorescent pseudomonads. Appl. Environ. Microbiol. 56:3576-3582.

Kawasaki, L., Wysong, D., Diamond, R., and Aguirre, J. 1997. Two divergent catalase genes are differentially regulated during Aspergillus nidulans development and oxidative stress. J. Bacteriol. 179:32843292.

Kikuchi-Torii, K., Hayashi, S., Nakamoto, H., and Nakamura, S. 1982. Properties of Aspergillus niger catalase. J. Biochem. 92:1449-1456.

Klotz, M. G., and Hutcheson, S. W. 1992. Multiple periplasmic catalases in phytopathogenic strains of Pseudomonas syringae. Appl. Environ. Microbiol. 58:2468-2473.

López-Medrano, R., Ovejero, M. C., Calera, J. A., Puente, P., and Leal, F. 1995. An immunodominant 90-kilodalton Aspergillus fumigatus antigen is the subunit of a catalase. Infect. Immun. 63:4774-4780.

Low, P. S., and Merida, J. R. 1996. The oxidative burst in plant defense: Function and signal transduction. Physiol. Plant. 96:533.542.

Mantle, P. G., and Nisbet, L. J. 1976. Differentiation of Claviceps purpurea in axenic culture. J. Gen. Microbiol. 93:321-334.

Mattern, I. E., Punt, P. J., van den Hondel, C. A. M. J. J. 1988. A vector of Aspergillus transformation conferring phleomycin resistance. Fungal Genet. Newsl. 35:25.

Mehdy, M. C. 1994. Active oxygen species in plant defense against pathogens. Plant Physiol. 105:467-472.

Müller, U. 1997. Struktur, Expression und gezielte Interaktivierung von cell, einem vermutlich Cellobiohydrolase-codierenden Gen von Claviceps purpurea. J. Cramer, Berlin.

Müller, U., Tenberge, K. B., Oeser, B., and Tudzynski, P. 1997. Cel1, probably encoding a cellobiohydrolase lacking the substrate binding domain, is expressed in the initial infection phase of Claviceps purpurea on Secale cereale. Mol. Plant-Microbe Interact. 10:268-279.

Nakagawa, C. W., Mutoh, N., and Hayashi, Y. 1995. Transcriptional regulation of catalase gene in the fission yeast Schizosaccharomyces pombe: Molecular cloning of the catalase gene and northern blot analyses of the transcript. J. Biochem. 118: 109-116.

Natvig, D. O., Sylvester, K., Dvorachek, W. H., Jr., and Baldwin, J. L. 1996. Superoxide dismutases and catalases. Pages 191-209 in: The Mycota III: Biochemistry and Molecular Biology. R. Brambl and G. A. Marzluf, eds. Springer-Verlag, Berlin.

Navarro, R. E., Stringer, M. A., Hansberg, W., Timberlake, W. E., and Aguirre, J. 1996. catA, a new Aspergillus nidulans gene encoding a developmentally regulated catalase. Curr. Genet. 29:352-359.

Okada, H., Ueda, M., Sugaya, T., Atomi, H., Mozaffar, S., Hishida, T., Teranishi, Y., Okazaki, K., Takechi, T., Kamiryo, T., and Tanaka, A. 1987. Catalase gene of the yeast Candida tropicalis. Eur. J. Biochem. 170:105-110.

Osbourn, A. E. 1996. Preformed antimicrobial compounds and plant defense against fungal attack. Plant Cell 8:1821-1831.

Otte, O., and Barz, J. 1996. The elicitor-induced oxidative burst in cultured chickpea cells drives the rapid insolubilization of two cell wall structural proteins. Planta 200:238-246.

Peng, M., and Kuc, J. 1992. Peroxidase-generated hydrogen peroxide as a source of antifungal activity in vitro and on tobacco leaf disks. Phytopathology 82:696-699.

Robertson, E. F., Dannelly, H. K., Malloy, P. J., and Reeves, H. C. 1987. Rapid isoelectric focusing in a vertical polyacrylamide minigel system. Anal. Biochem. 167:290-294.

Sambrook, J., Fritsch, E. F., and Maniatis, T. A. 1989. Molecular Cloning: A Laboratory Manual. 2nd ed. Cold Spring Harbor Laboratory, Cold Spring Harbor, NY.

Schüller, C., Brewster, J. L., Alexander, M. R., Gustin, M. C., and Ruis, H. 1994. The HOG pathway controls osmotic regulation of transcription via the stress response element (STRE) of Saccharomyces cerevisiae CTT1 gene. EMBO J. 13:4382-4389.

Smit, R., and Tudzynski, P. 1992. Efficient transformation of Claviceps purpurea using pyrimidine auxotrophic mutants cloning of the OMP decarboxylase gene. Mol. Gen. Genet. 234:297-305.

Tenberge, K. B., Homann, V., Oeser, B, and Tudzynsk, P. 1996. Structure and expression of two polygalacturonase genes of Claviceps purpurea oriented in tandem and cytological evidence for pectinolytic enzyme activity during infection of rye. Phytopathology 86:10841097.

Tudzynski, P., Tenberge, K. B., and Oeser, B. 1995. Claviceps purpurea. Pages 161-187 in: Pathogenesis and Host Specificity in Plant Diseases: Histopathological, Biochemical, Genetic and Molecular Bases, Vol. II, Eukaryotes. K. Kohmoto, U. S. Singh, and R. P. Singh, eds. Elsevier Science, Pergamon Press, Oxford.

Van der Vlugt-Bergmans, C. J. B., Wagemakers, C. A. M., Dees, D. C. T., and van Kan, J. A. L. 1997. Catalase A from Botrytis cinerea is not expressed during infection on tomato leaves. Physiol. Mol. Plant Pathol. 50:1-15.

von Heijne, G. 1983. Patterns of amino acids near signal-sequence cleavage sites. Eur. J. Biochem. 133:17-21.

Wasserman, B. P., and Hultin, H. O. 1981. Effect of deglycosylation on the stability of Aspergillus niger catalase. Arch. Biochem. Biophys. 212:385-392.

Wood, W. B. 1966. Host specificity of DNA produced by Escherichia coli: Bacterial mutations affecting the restriction and modification of DNA. J. Mol. Biol. 16:118-133.

Witteveen, C. F. B., Veenhuis, M., and Visser, J. 1992. Localization of glucose oxidase and catalase activities in Aspergillus niger. Appl. Environ. Microbiol. 58:1190-1194.

Wu, G., Shortt, B. J., Lawrence, E. B., Levine, E. B., Fitzsimmons, K. C., and Shad, D. M. 1995. Disease resistance conferred by expression of a gene encoding $\mathrm{H}_{2} \mathrm{O}_{2}$-generating glucose oxidase in transgenic potato plants. Plant Cell 7:1357-1368.

Zhang, Z., Collinge, D. B., and Thordal-Christensen, H. 1995. Germinlike oxalate oxidase, a $\mathrm{H}_{2} \mathrm{O}_{2}$-producing enzyme, accumulates in barley attacked by the powdery mildew fungus. Plant J. 8:139-145. 